\title{
AN UNKNOWN OPISTHOBRANCH (MOLLUSCA: GASTROPODA) IN THE MAGELLAN REGION (TOLEDONIA PARELATA DELL, 1990): NEW RECORDS AND SIMILAR SPECIES
}

\author{
UN IGNOTO OPISTOBRANQUIO (MOLLUSCA: GASTROPODA) EN \\ LA REGIÓN DE MAGALLANES (TOLEDONIA PARELATA DELL, \\ 1990): NUEVOS REGISTROS Y ESPECIES SIMILARES
}

Sebastián Rosenfeld ${ }^{1} \&$ Cristian Aldea ${ }^{2}$

Great part of knowledge generated on mollusks from the Magellan Region has been recorded from numerous expeditions during the last century. However, literature is scattered on some groups of species and information with regard to habitat and ecology is difficult to find. This is the case on the species of the genus Toledonia Dall, 1902 (Opisthobranchia, Diaphanidae). For the Magellan Region (excluding the Falkland/Malvinas Islands) five species have been reported: Toledonia perplexa Dall, 1902, T. vagabunda (Mabille, 1885), T. limnaeaeformis (Smith, 1877), T. punctata Thiele, 1912 and T. parelata Dell, 1990. Some studies, however, have focused on T. vagabunda (Mabille 1885, Strebel 1905), on T. perplexa (Dall 1902, Powel 1951, Marcus 1976, Dell 1990), on T. punctata (Thiele 1912, Dell 1990), and on T. limnaeaeformis (Marcus 1976, Dell 1990, Linse 2002). Despite the contribution made by these authors, the information related to this genus is difficult to find.

The identification of Toledonia species is difficult to do, because they belong to small animals that present a similar external morphology and can be confused with similar species. Some of the recognizable external features for some species include: T. vagabunda presents spiral grooves in the shell; $T$. punctata presents punctae arranged in spiral lines in the protoconch and first whorl of the teleoconch; and T. parelata presents less convex whorls giving a conical spire outline. With regard to T. perplexa and T. limnaeaeformis, Marcus (1976) separated these species by their D/H ratio; however, there is a considerable taxonomic controversy for the two species due to confusing diagnostic characters that separate them. Furthermore, there is not enough information about these species in the Magellan Region. Within the abovementioned species, the only one that has not been recorded or sought in the area of the Magellanic channels is $T$. parelata, since its distribution range from $53.7^{\circ} \mathrm{S}-54.9^{\circ} \mathrm{S}$ and $66.3^{\circ} \mathrm{W}-65.1^{\circ}$ W (Morris \& Rosenberg, 2005) (Fig. 1), makes it a species of the South Atlantic Ocean. The aim of this work is to report new data on the geographic location and bathymetry of $T$. parelata and to carry out a comparison with similar species of the genus.

1 Laboratorio de macroalgas antárticas y subantárticas, Universidad de Magallanes.

2 Centro de Estudios del Cuaternario de Fuego-Patagonia y Antártica (Fundación CEQUA); Universidad de Magallanes. 


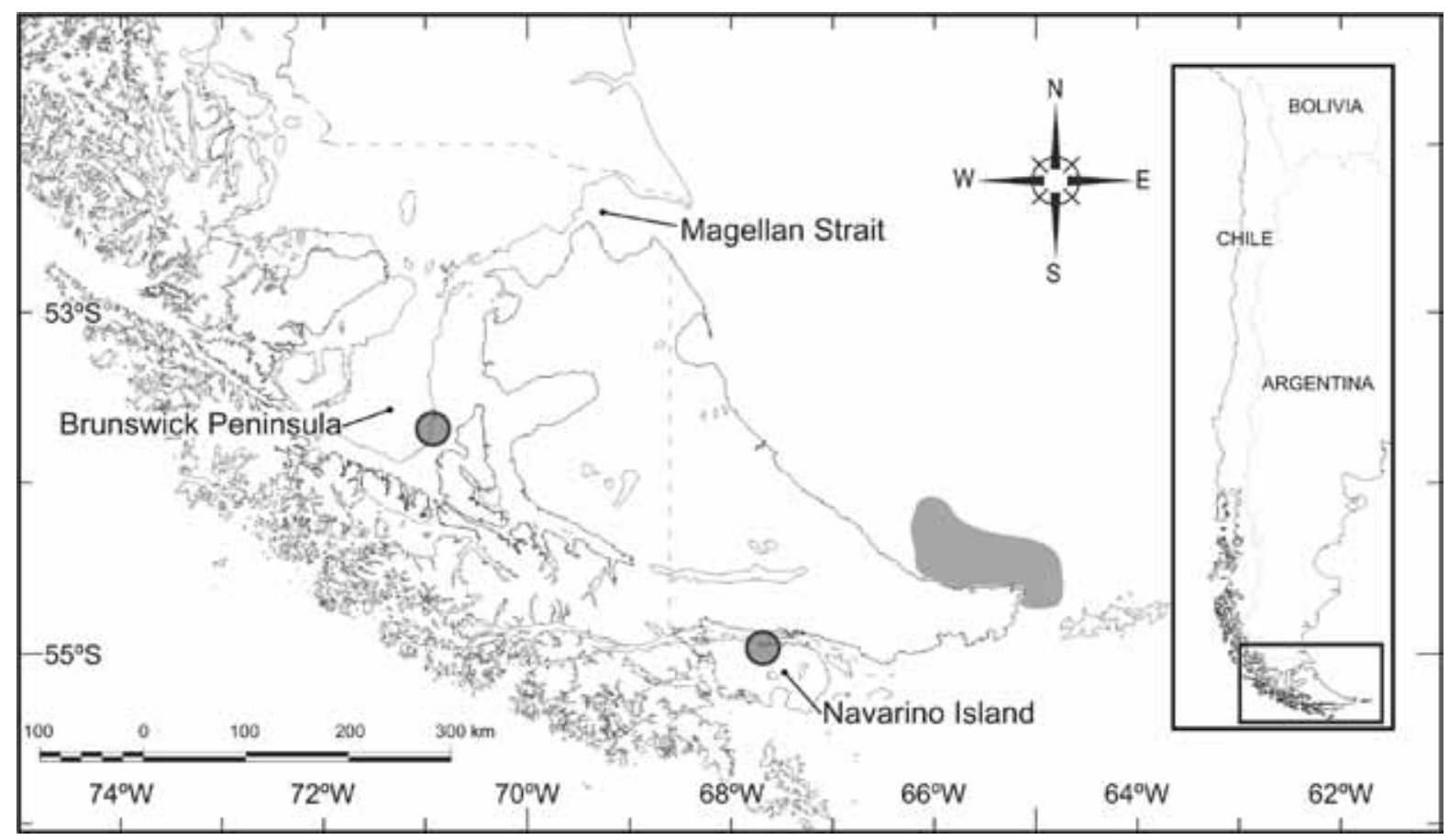

Fig. 1. Map of geographic distribution of Toledonia parelata, indicating previous distribution (shadow) and two new records (circles) in Navarino Island (Beagle Channel) and Brunswick Peninsula (Magellan Strait).

Ten specimens were collected and thoroughly analyzed. The individuals were obtained in the intertidal area of Róbalo Bay $\left(55.08^{\circ} \mathrm{S}, 67.58^{\circ}\right.$ W; Navarino Island; Fig. 1) and Punta Carrera (53.60 ${ }^{\circ} \mathrm{S}, 70.92^{\circ} \mathrm{W}$; Magellan Strait; Fig. 1). The specimens were collected alive and they were fixed in buffered-70\% ethanol fixative, examined and photographed in the laboratory.

All individuals correspond to mature specimens (Fig. 2A, B, C), but not as developed as the holotype housed in USNM. The holotype of this specie was described from the east of Tierra del Fuego in South Atlantic Ocean $\left(53.70^{\circ} \mathrm{S}, 66.32^{\circ}\right.$ $\mathrm{W})$ in $81 \mathrm{~m}$ presenting six whorls and a large shell. Our specimens presented 4-5 whorls with a conical spire outline, a smooth teleoconch with prosocline growth lines, slightly marked sutures and not very convex borders. The presentation of this report confirms the presence of Toledonia parelata in the Magellan Strait and Beagle Channel; giving new data of shallower bathymetry (see Fig. 1, Table 1).

Considering all species of the genus Toledonia in seawaters of the southern hemisphere, the most similar is the Antarctic species Toledonia elata Thiele, 1912 (Fig. 3A), as well as our specimens of T. parelata, both of which present five whorls and a straight columella, but exhibits a more lengthened

Table 1. Distribution and bathymetry of the five species of Toledonia in the Magellan Region.

\begin{tabular}{|l|l|l|l|}
\hline Species & Distribution & Bathymetry $(\mathrm{m})$ & Source \\
\hline T. vagabunda & $55-56^{\circ} \mathrm{S} ; 65-68^{\circ} \mathrm{W}$ & 10 & Morris \& Rosenberg (2005) \\
\hline T. perplexa & $41.5-56.3^{\circ} \mathrm{S} ; 57.2^{-7} 5^{\circ} \mathrm{W}$ & $2-229$ & Dell (1990) \\
\hline T. punctata & $46-55.8^{\circ} \mathrm{S} ; 180-36.5^{\circ} \mathrm{W}$ & $115-567$ & Dell (1990) \\
\hline T. parelata & $53.7-55.1^{\circ} \mathrm{S} ; 65.1-70.9^{\circ} \mathrm{W}$ & $0-229$ & Dell (1990), this work \\
\hline T. limnaeaeformis & Kerguelen $^{*}$ & no data & Dell (1990) \\
\hline
\end{tabular}

*Toledonia limnaeaeformis has been misidentified by various authors in the Magellan Region, but that records are referred really to T. perplexa (see Morris \& Rosenberg 2005). However more diagnostic features are required to differentiate both species and to elucidate the truthful distribution of T. limnaeaeformis. 


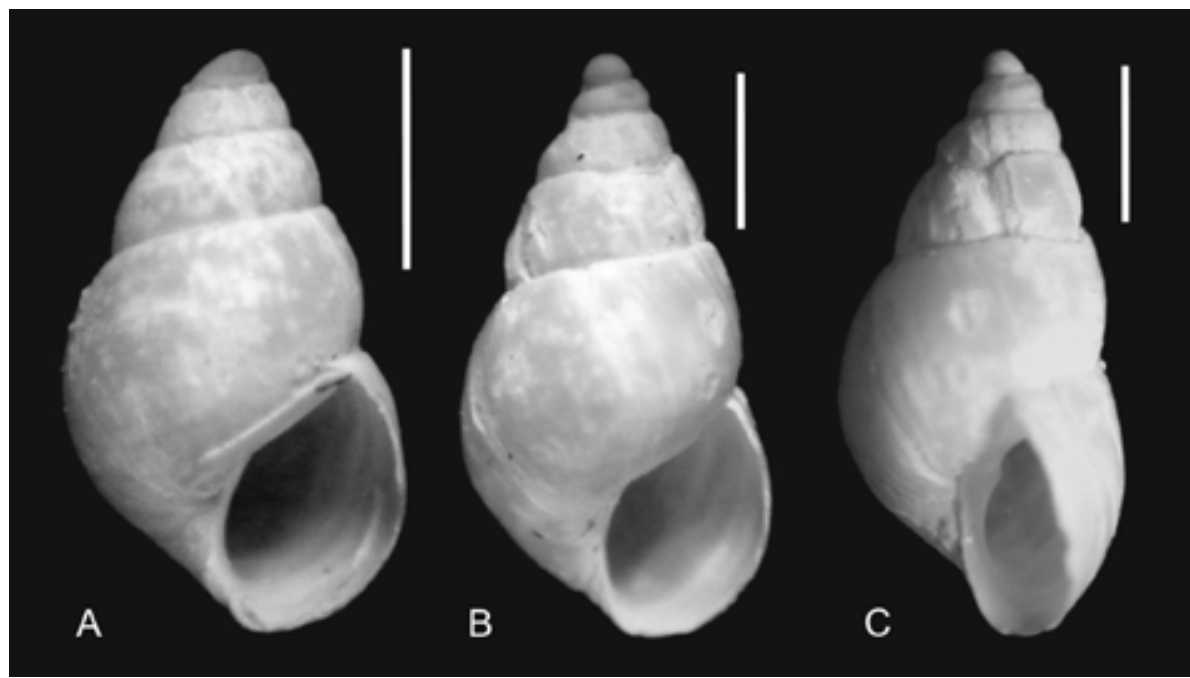

Fig. 2. Toledonia parelata; A, apertural view of specimen from Robalo Bay, Navarino Island; B, C, apertural and lateral views of specimen from Punta Carrera, Brunswick Peninsula. Scale bars: $1 \mathrm{~mm}$.

shell -mainly its aperture- and it presents fairly spiral sculpture. Further research and new data on the genus from Magellan coasts should elucidate the distribution of the several species, especially referred to $T$. perplexa and T. limnaeaeformis (Fig. $3 \mathrm{~B}-\mathrm{C}$, respectively).

\section{ACKNOWLEDGEMENTS}

We would like to thank Jen Hammock (Invertebrate Zoology, NMNH) for pictures of USNM specimens of Toledonia perplexa, José Templado (Spanish Malacological Society) and Jesús Troncoso (University of Vigo, Spain) for kindly provided literature. We also thank Ricardo Rozzi, Andrés Mansilla and Jaime Ojeda (University of Magallanes and Institute of Ecology and Biodiversity) for their valuable support in fieldworks and the Omora Park for its hospitality in Puerto Williams (Beagle Channel). Finally, we thank Silvia Murcia, Gonzalo Rosenfeld, and Esteban Mimica for their assistance with English. We also would like to thanks two anonymous referees.
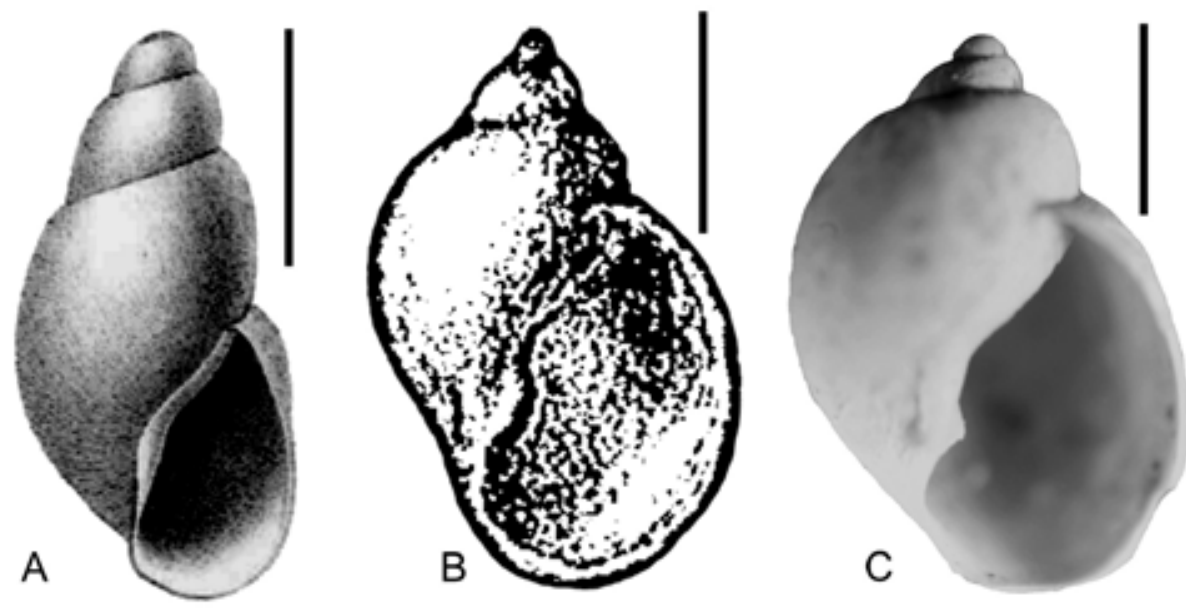

Fig. 3. A, Toledonia elata, original drawing from Thiele (1912); B, 116 T. limnaeaeformis, redrawing from Smith (1879); C, T. perplexa, holotype USNM 109022. Scale bar: $1 \mathrm{~mm}$. 


\section{LITERATURE CITED}

Dall, W.H. 1902. Illustrations and descriptions of new, unfigured, or imperfectly known shells, chiefly American, in the U. S. National Museum. Proceedings of the United States National Museum, 24(1264):499-566

Dell, R.K. 1990. Antarctic Mollusca, with special reference to the fauna of the Ross Sea. Bulletin of the Royal Society of the New Zealand, 27:1-311

Linse, K. 2002. The shelled Magellanic Mollusca: with special reference to biogeography relations in the Southern Ocean. A.R.G. Gantner Verlag KG, Ruggell. Theses Zoologicae, 34:1-252

Mabille, J. 1885. Descriptions de deux mollusques marins du Cap Horn. Bulletins de la Société Malacologique de France, 2:207-208

Marcus, E.D. 1976. A taxonomic survey of the genus Toledonia Dall, 1902 (Opistobranchia, Diaphanidae). Zoologica Scripta, 5:25-33
Morris, P.J. \& G. Rosenberg 2005. Search interface and documentation for Malacolog, an online database of Western Atlantic marine Mollusks. [WWW database (version 4.1.1)] URL: http:// www.malacolog.org. (Accessed in August, 15th, 2010)

Powel, A.W.B. 1951. Antarctic and Subantartic Mollusca: Pelecypoda and Gastropoda. Discovey Reports, 26:47-126

Smith, E.A. 1879. Mollusca. An account of the petrological, botanical, and zoological collections made in Kerguelen's Land and Rodriguez. Philosophical Transactions of the Royal Society of London, 168:167-192

Strebel, H. 1905. Beiträge zur Kenntnis der Molluskenfauna der Magalhaen-Provinz. No. 3. Zoologische Jahrbücher, Abteilung für Systematik, Geographie und Biologie der Tiere, 22:575-666

Thiele, J. 1912. Die antarktischen Schnecken und Muscheln. Deutsche Südpolar-Expedition 1901-1903, 13:183-286, pls. 11-19. Georg Reimer. Berl 